\title{
Characterization of the maturation process by changes in pineapple fruit texture.'
}

\author{
Humberto Vega-Mercado* and Isabel Beauchamp de Calonis
}

\begin{abstract}
An objective indicator of the ripening level of fruit is the peel texture. A texturometer was used to determine the penetration stress as a function of ripening time in mature-green pineapples (Red Spanish). The ripening was achieved under controlled temperature $\left(65^{\circ} \mathrm{F}\right)$ and relative humidity $(85 \%)$ conditions. Penetration stress as a function of ripening time showed significant differences. These differences were used to classify the ripening stage of the fruit. Meanwhile, pineapples showed a penetration stress profile which coincided with the traditional ripening classification in terms of the peel color and its distribution on the fruit.
\end{abstract}

\section{RESUMEN}

Determinación del proceso de madurez de la piña a base de los cambios en la textura

Una manera objetiva para determinar la madurez de las frutas es en función de la textura de la cáscara. Con un texturómetro se midió el esfuerzo de penetración en función del tiempo de maduración para la piña (variedad Española roja). Las frutas se maduraron bajo condiciones controladas de temperafura $\left(65^{\circ} \mathrm{F}\right)$ y humedad relativa $(85 \%)$. Se encontró una relación entre la dureza de la cáscara de la fruta y la madurez. En el caso de la piña, además hay diferencias significativas a lo largo del fruto que coinciden con la manera tradicional de clasificar la madurez de la piña en términos del color de la cáscara y su proporción en la fruta.

\section{INTRODUCTION}

Post harvest chemical changes have made it necessary to develop mechanisms to determine optimum ripening level at which fruits and vegetables should be harvested. This holds true both for products destined for the fresh market and for those that will subsequently be processed.

The differences between physiological maturity and commercial maturity (Fig. 1) were studied by Wills et al: (8). They discussed the use of mechanical tests to establish the maturity level of vegetables such as peas. Other criteria used to characterize maturity levels are color, electrical or light transmittance, chemical composition, size and shape, and harvest time.

'Manuscript submitted to Editorial Board 23 February 1989. We express our gratitude to Miss Irvis Pagan for her assistance in the laboratory analyses of samples. We also thank the Land Authority of Puerto Rico for supplying us with mature-green pineapples.

"Research Assistant, Food Technology Laboratory.

"Food Technologist, Food Technology Laboratory. 


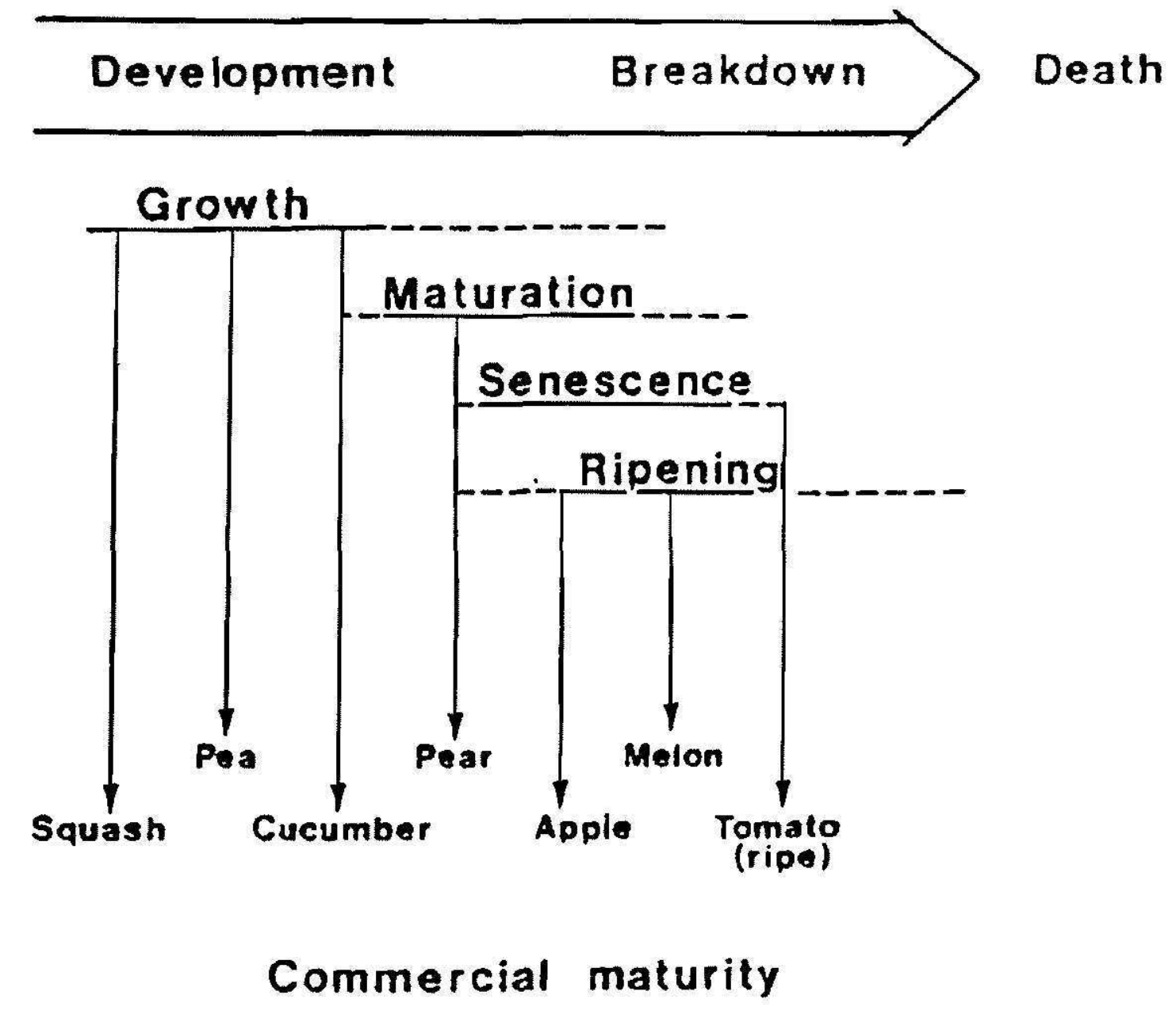

Frg. 1.-Physiological and commercial maturity of some products (Wills et al. (8)).

Cancel and García (5) determined the harvesting date for the total fruit production of one mango tree in terms of size and ripeness of fruit. Wang and Chang (7) carried out mechanical tests on papaya. They reported the relationship between maturity level and the strain caused by a constant load stress. Other mechanical tests have been developed to study the ripening of fruits $(2,3,4,6)$.

Pineapples have a particular ripening pattern: the change in color begins from the bottom to the top of the fruit. Ripening is classified accordingly as $1 / 4,1 / 2,3 / 4$, and fully mature. The main objective of this work is to establish the stress profile in terms of pineapple ripening time and to compare the profile against the traditional method of ripening classification based on fruit color.

\section{MATERIALS AND METHODS}

\section{Storage and ripening of fruits}

Twenty Red Spanish pineapples were obtained from the Land Authority of Puerto Rico in the mature-green stage. After visual inspection, 
J. Agric. Univ. P.R. vol. 73, No. 3, JULY, 1989

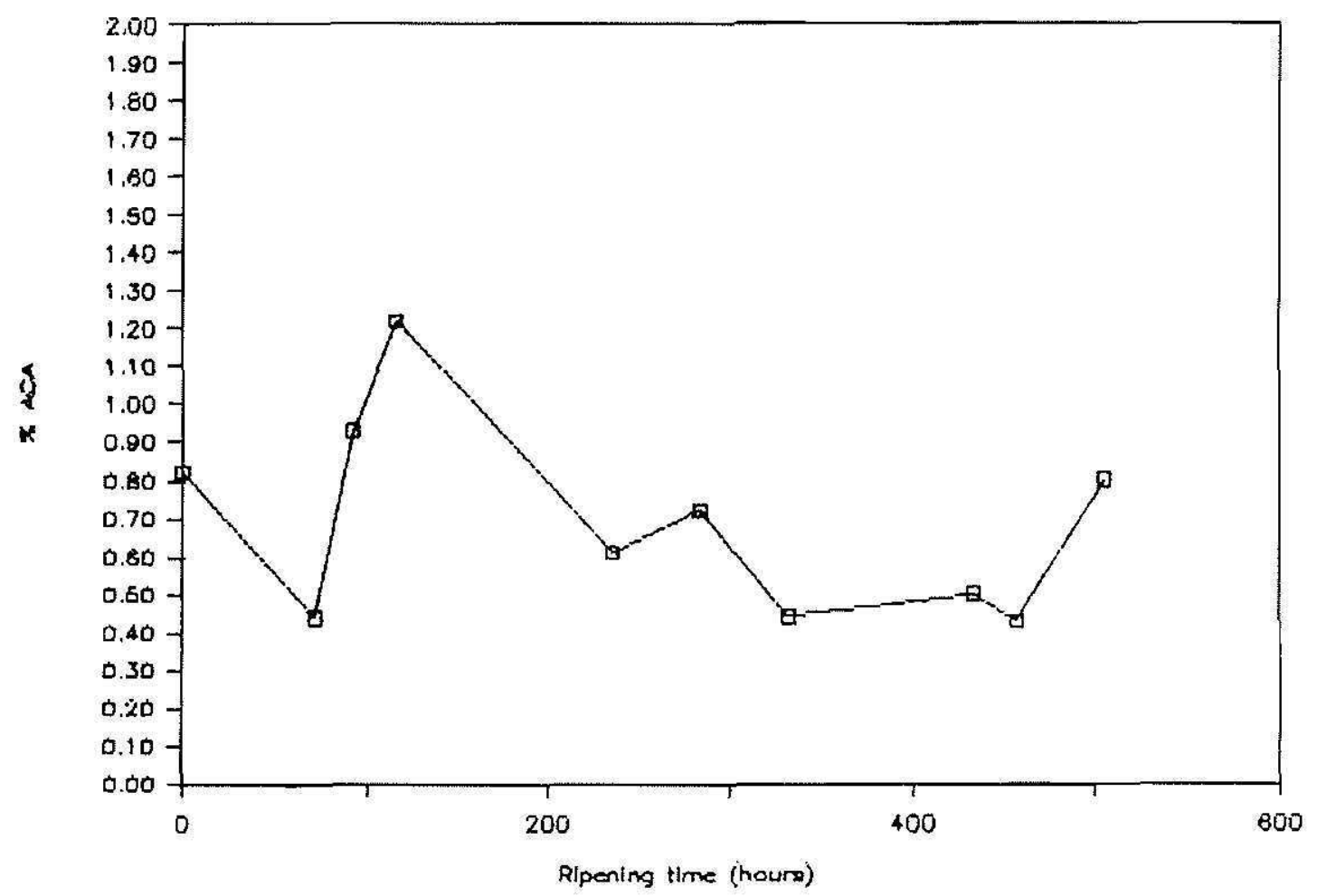

FIG. 2.-Total acidity as a function of ripening time in pineapple juice.

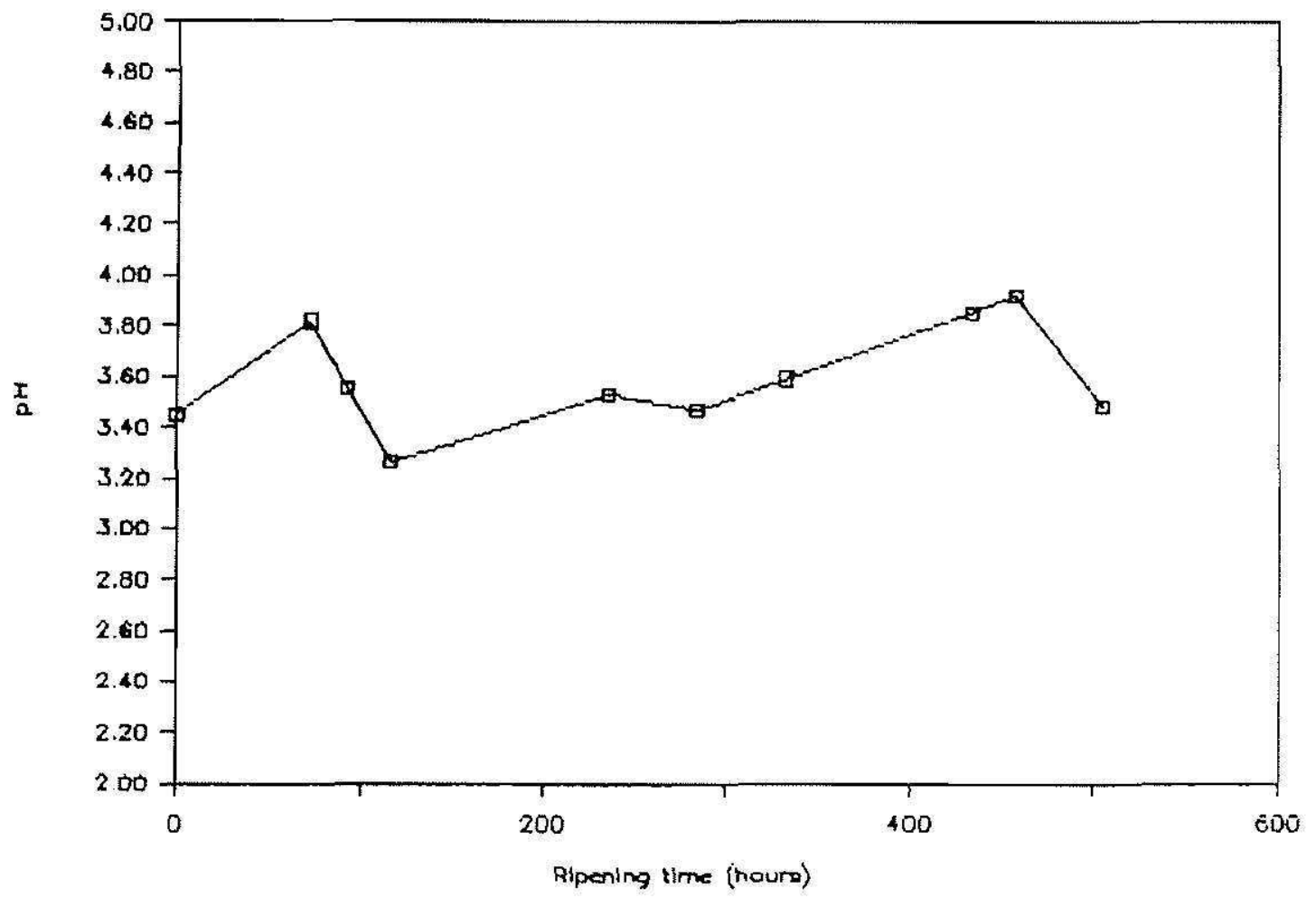

FIc. 3. $-\mathrm{pH}$ as a function of ripening time in pineapple juice. 
the fruits were stored at $65^{\circ} \mathrm{F}$ and $85 \%$ relative humidity until penetration tests were performed. Monitoring of the ripening process began the moment the fruits were placed in the maturation chamber, not counting the time required to move the fruits from the field to the laboratory.

\section{Analytical tests}

The pineapple juice was tested according to the methods recommended by the A.O.A.C. (1): $\mathrm{pH}$, ${ }^{\circ} \mathrm{Brix}$, and acidity.

\section{Color measurements}

A spectrocolorimeter Lab Scan II (Hunter-Lab, New York, N.Y.)" was used to measure the peel color of pineapple in terms of the $L, a, b$ parameters as a function of ripening time. The $\mathrm{L}$ parameter measures the intensity in terms of darkness. The a parameter measures the red/ green intensity and the b parameter measures the yellow/blue intensity.

\section{Penetration tests}

A FAC texturometer (Model T-2100 CI, Food Technology Corp., Rockville, MA) was used in the penetration tests. A constant load of 200

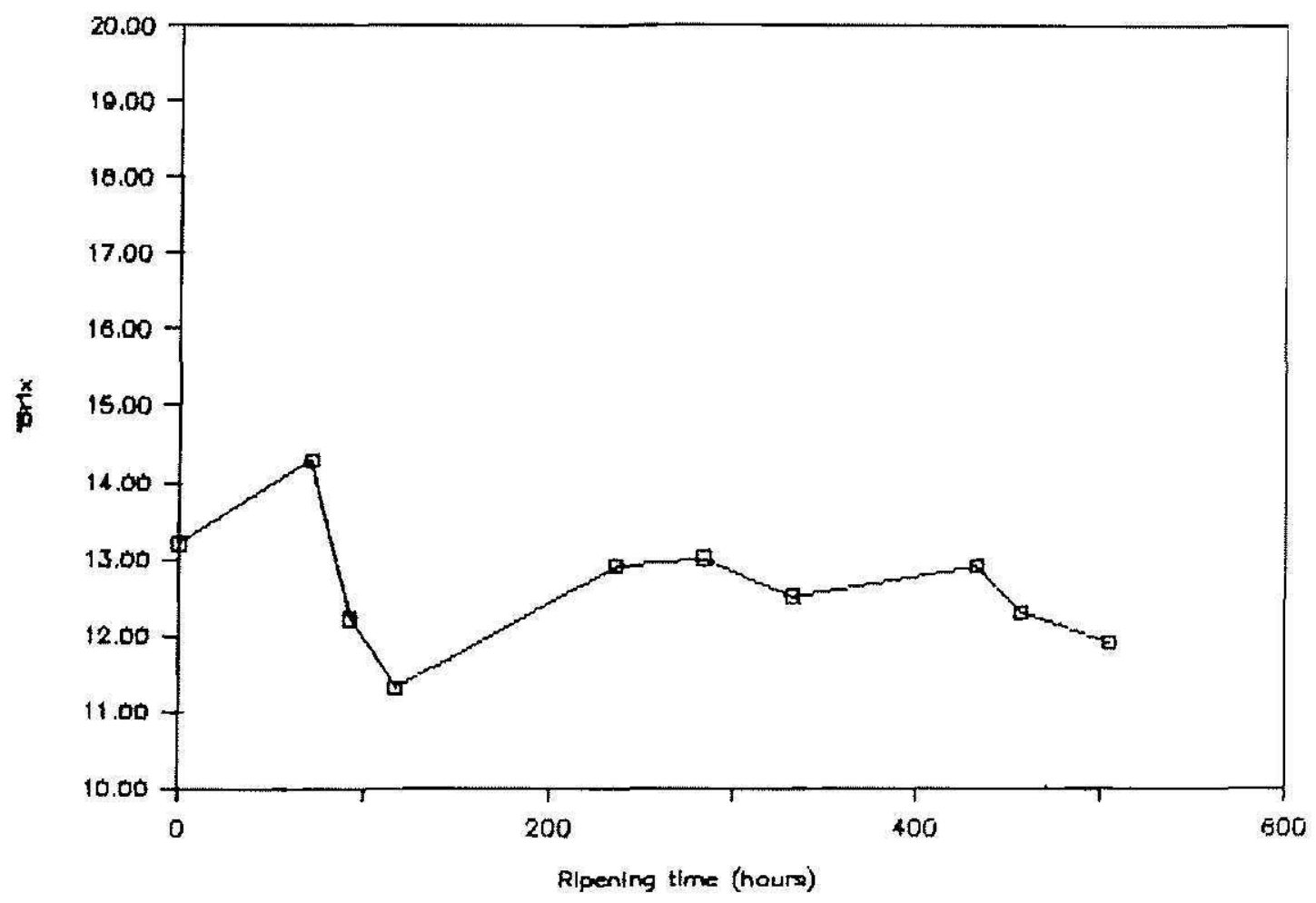

FIG. 4.-Soluble solid content as a function of ripening time in pineapple juice.

4Trade names are used solely for the purpose of providing specific information. Mention of trade names does not constitute a guarantee or warranty by the Agricultural Experimental Station of the University of Puerto Rico or an endorsement over other equipments not mentioned. 
J. Agric. Univ. P.R. vol. 73, No. 3, JULY, 1989

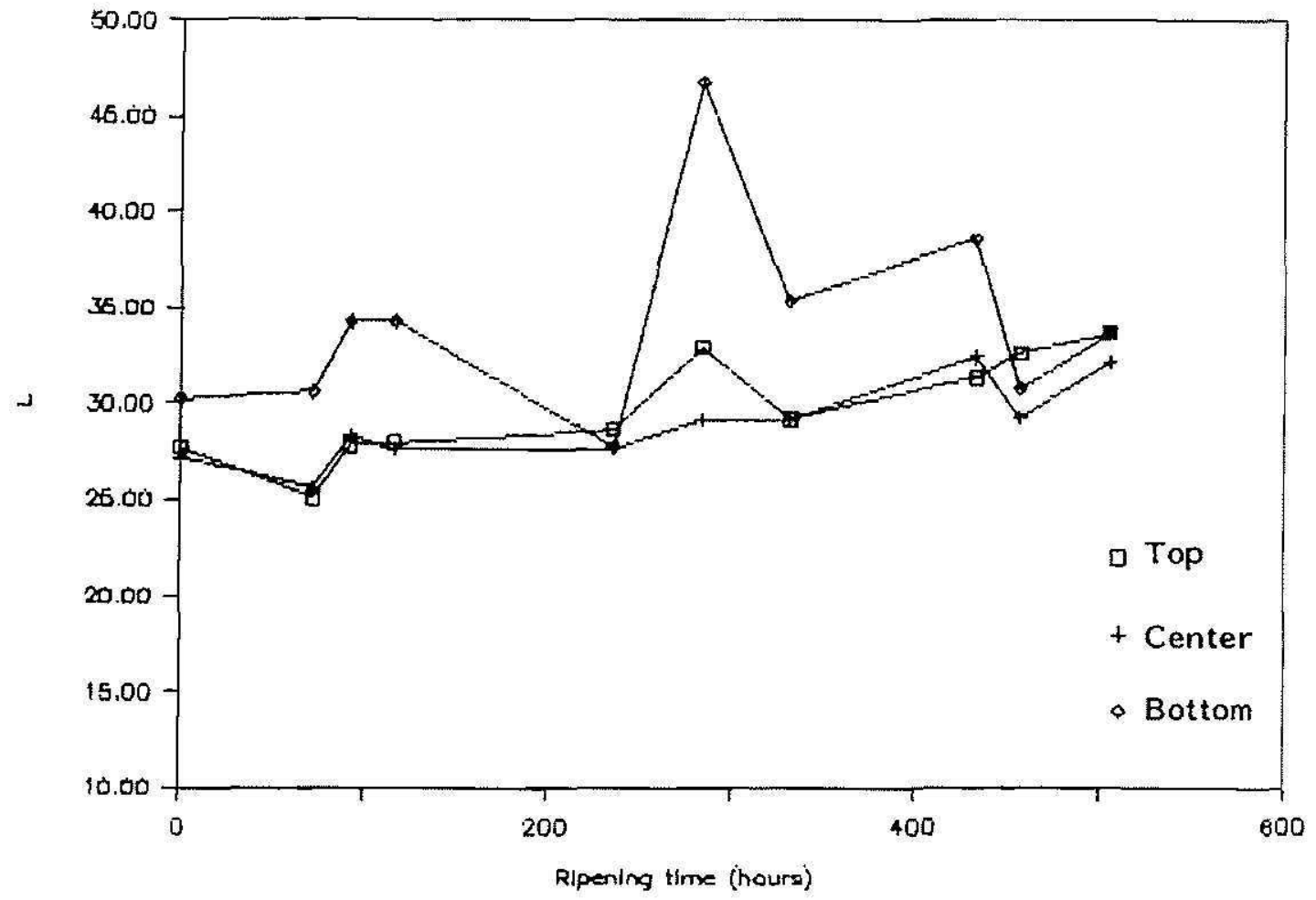

FIG. 5.-Parameter " $L$ " of Hunter scale as a function of ripening time in pineapple peel.

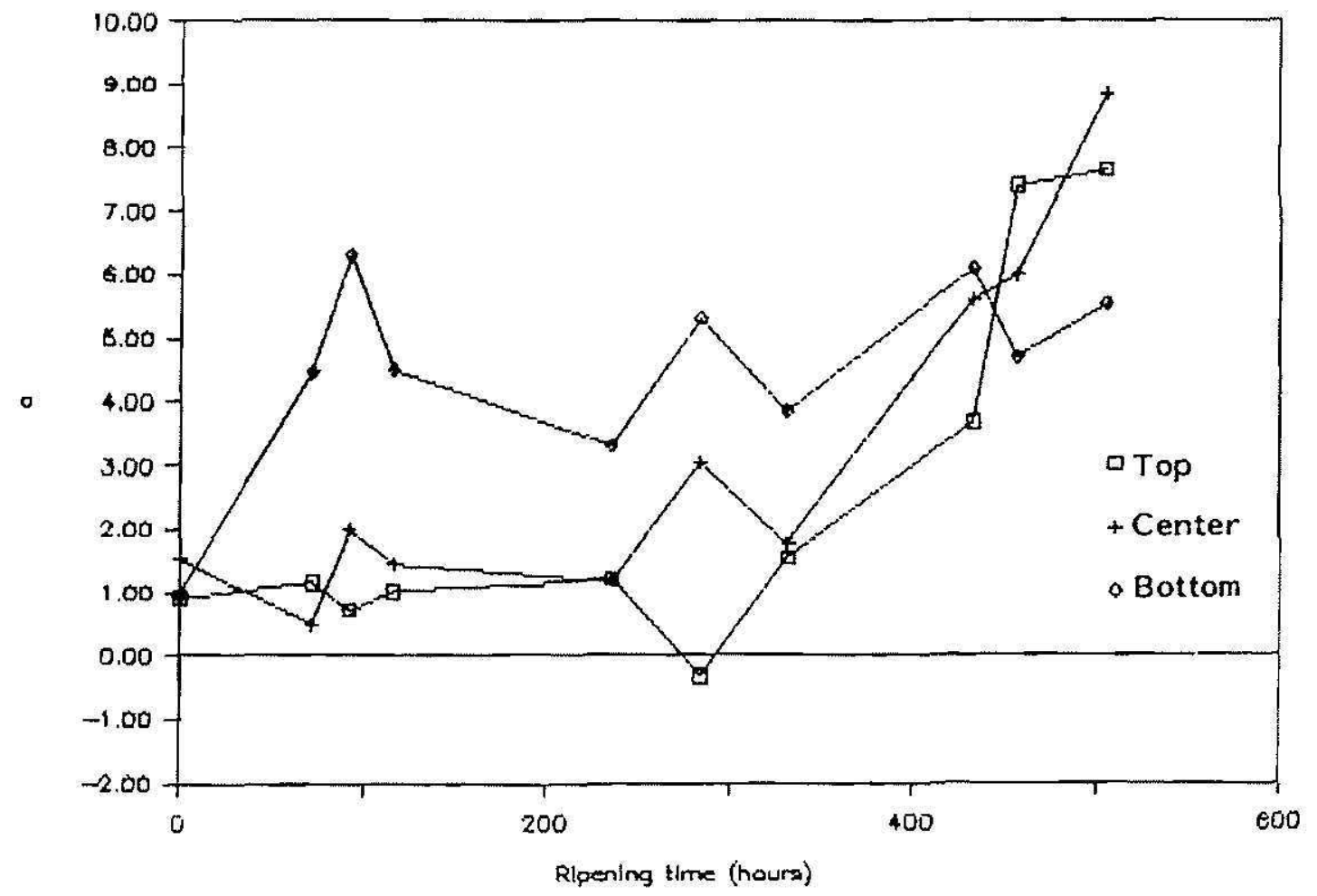

FIG. 6.-Parameter "a" of Hunter scale as a function of ripening time in pineapple peel. 
psi was applied at 3 different velocities: $0.153 \mathrm{~cm} / \mathrm{s}, 0.366 \mathrm{~cm} / \mathrm{s}$, and 0.600 $\mathrm{cm} / \mathrm{s}$. A $2.0 \mathrm{~mm}$ diameter rod was used in the hydraulic piston as a penetrometer.

Fruits were divided in 6.25 to $7.50 \mathrm{~cm}$ wide sections. Each section was identified as top, center, and bottom. Two samples of each section were tested and the maximum stress of penetration was recorded. This stress was used to characterize the ripening process in the fruit.

\section{Sensory evaluation}

An acceptability test for flavor and texure was performed as a function of ripening time. A scale of +2 (most acceptable) to -2 (not acceptable) was used for each case by an 8- to 10-member taste panel.

\section{Statistical analysis of penetration results}

The experimental design followed a nested-factorial model. Two effects were nested: Section (top, center, and bottom), and ripening time. The penetration velocity was the third effect studied. The significance level was set to $5 \%$.

\section{RESULTS AND DISCUSSION}

The ripening of pineapple took 21 days at the controlled conditions of $85 \%$ relative humidity and $65^{\circ} \mathrm{F}$. The peel color changed from dark green to red-yellow. The change of color followed a uniform pattern: from bottom to top of the fruit.

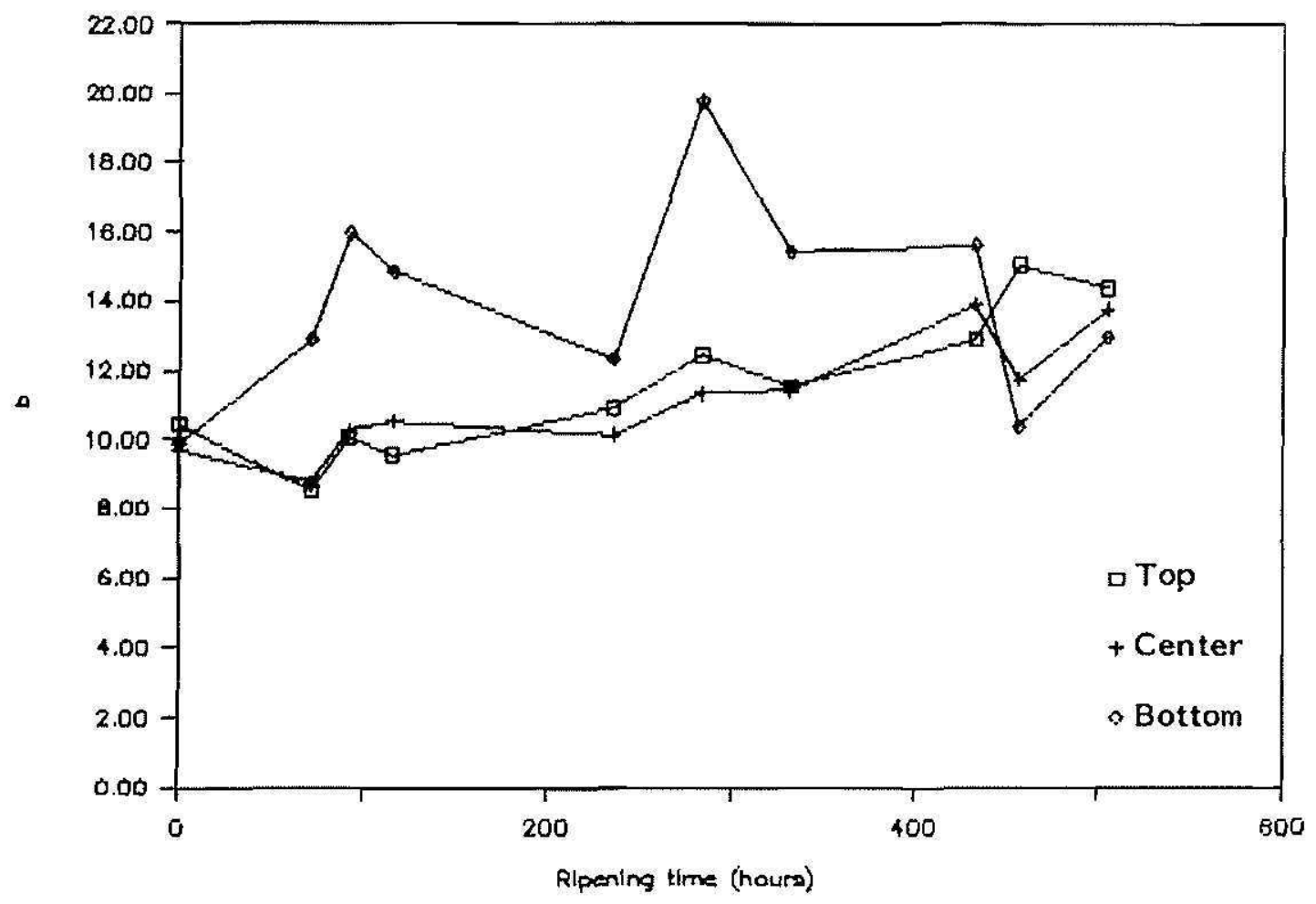

FIG. 7.-Parameter "b" of Hunter scale as a function of ripening time in pineapple peel. 
J. Agric. Univ. P.R. vol. 73, No. 3, JULY, 1989

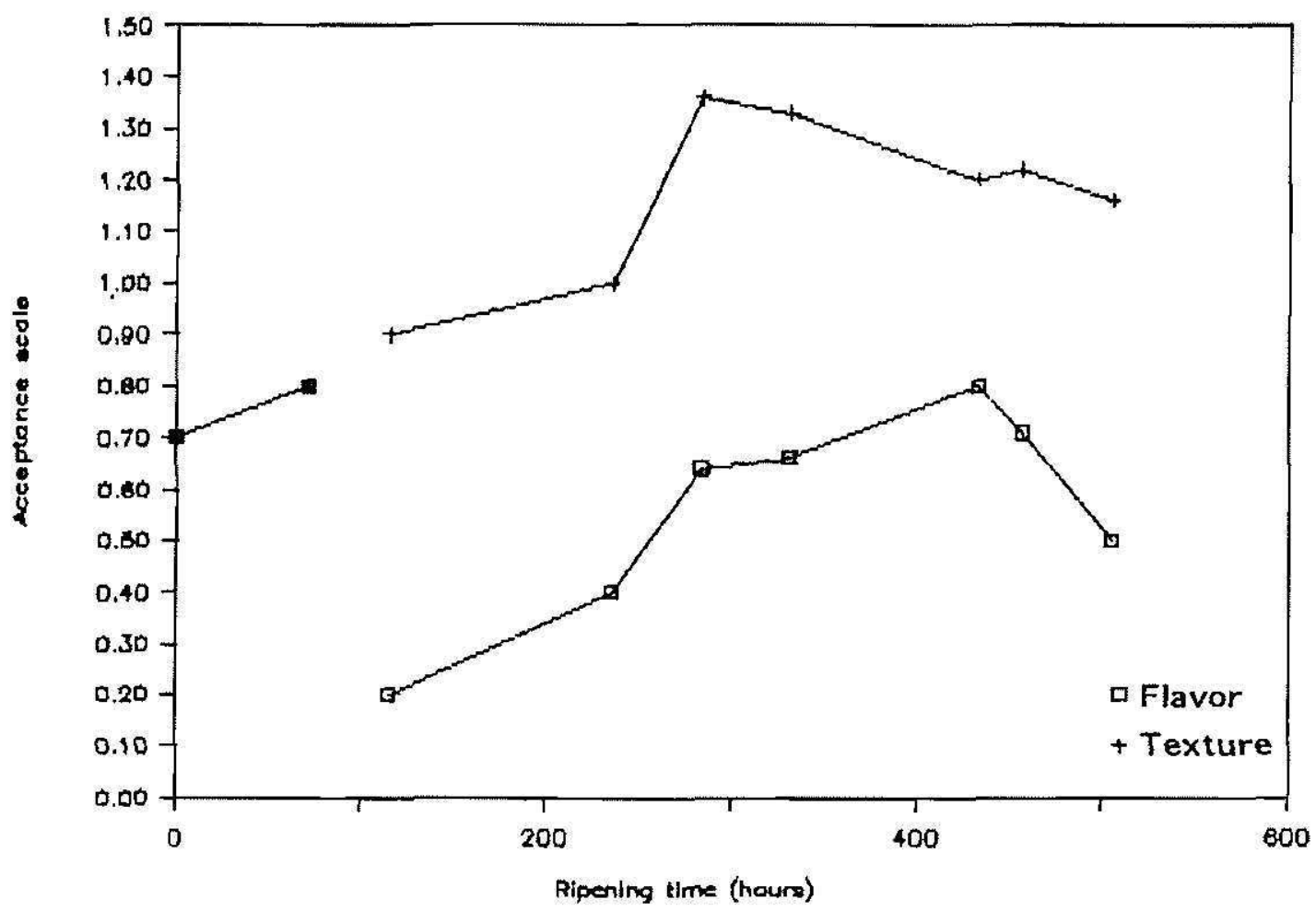

FIG. 8.-Sensory evaluation of pineapple syrup as a function of ripening time.

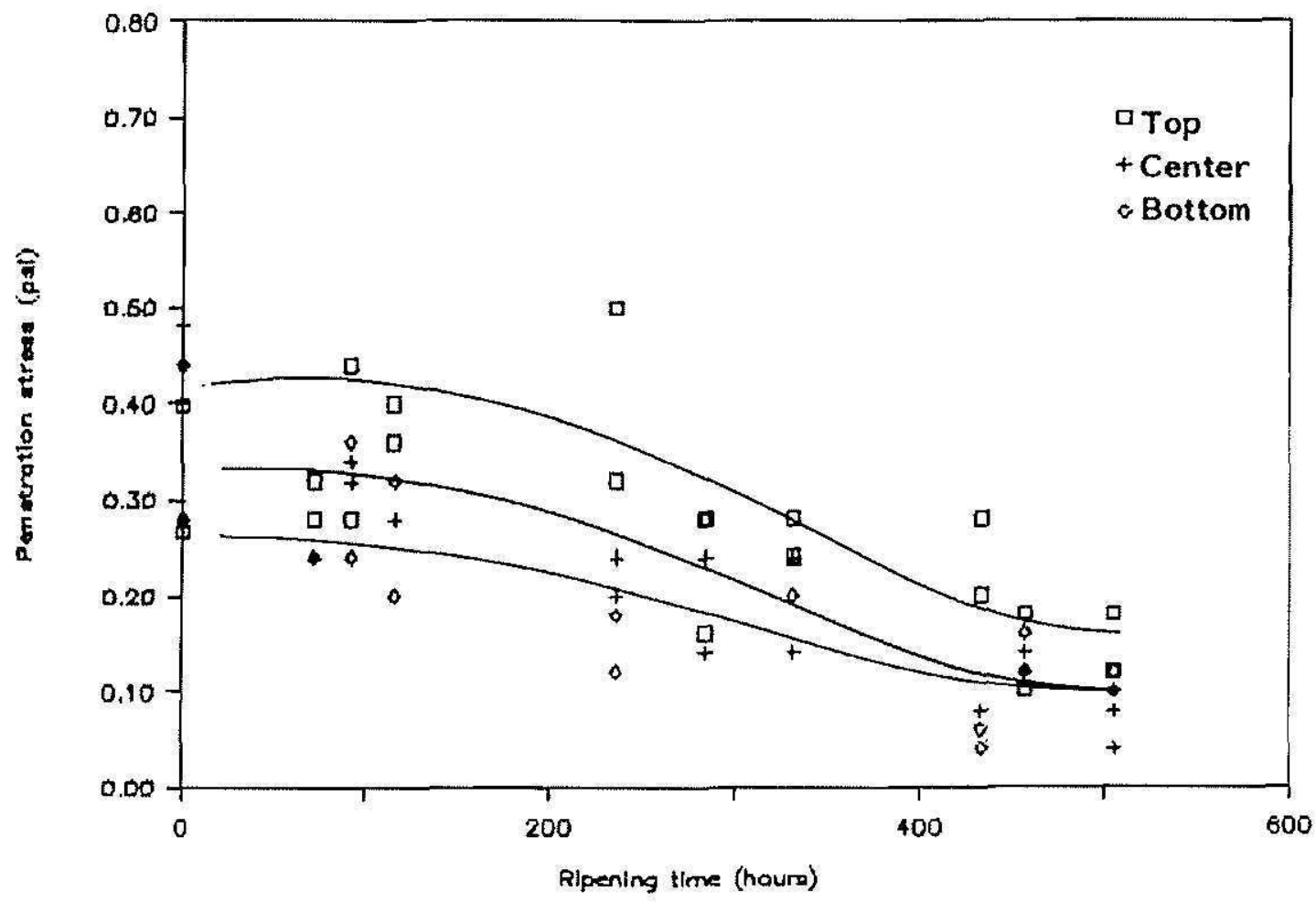

FyG. 9.-Ripening profiles of pineapple fruit at $0.153 \mathrm{~cm} / \mathrm{s}$ penetration velocity. 
The analytical tests showed a reduction in acidity: from 5 eq. $\mathrm{NaOH} /$ gram to 3 eq. NaOH/gram. The $\mathrm{pH}$ was in the range of 3.25 to 3.75 . The soluble solid content was in the range of 12.25 to $12.50^{\circ}$ Brix. Figures 2, 3 and 4 are plots of the above parameters in terms of ripening time.

Figures 5, 6 and 7 are plots of the color parameters " $\mathrm{L}$ ", "a", and "b" in terms of the ripening time. Parameter " $\mathrm{L}$ " had a linear response as a function of time. A similar response was observed in parameter "b", but parameter "a" showed a nonlinear behavior.

Sensory evaluation tests showed an improvement in fruit acceptability in terms of flavor and texture as the ripening process progresses, as expected. Figure 8 shows the sensory eveluation parameters as a function of time.

The penetration tests were done at three different velocities: 0.153 $\mathrm{cm} / \mathrm{s}, 0.366 \mathrm{~cm} / \mathrm{s}$, and $0.600 \mathrm{~cm} / \mathrm{s}$. The results for each case were similar in terms of curve behavior, but an analysis of variance showed significant differences $(P=0.05)$ between the stress values for each velocity. The differences among sections of pineapple (top, center and bottom) were sigificant $(P=0.05)$; the stress profiles showed these differences. Nevertheless, an increase in penetration velocity caused a reduction in profile differences. Figures 9, 10, and 11 are plots of the experimental data of penetration tests for each velocity.

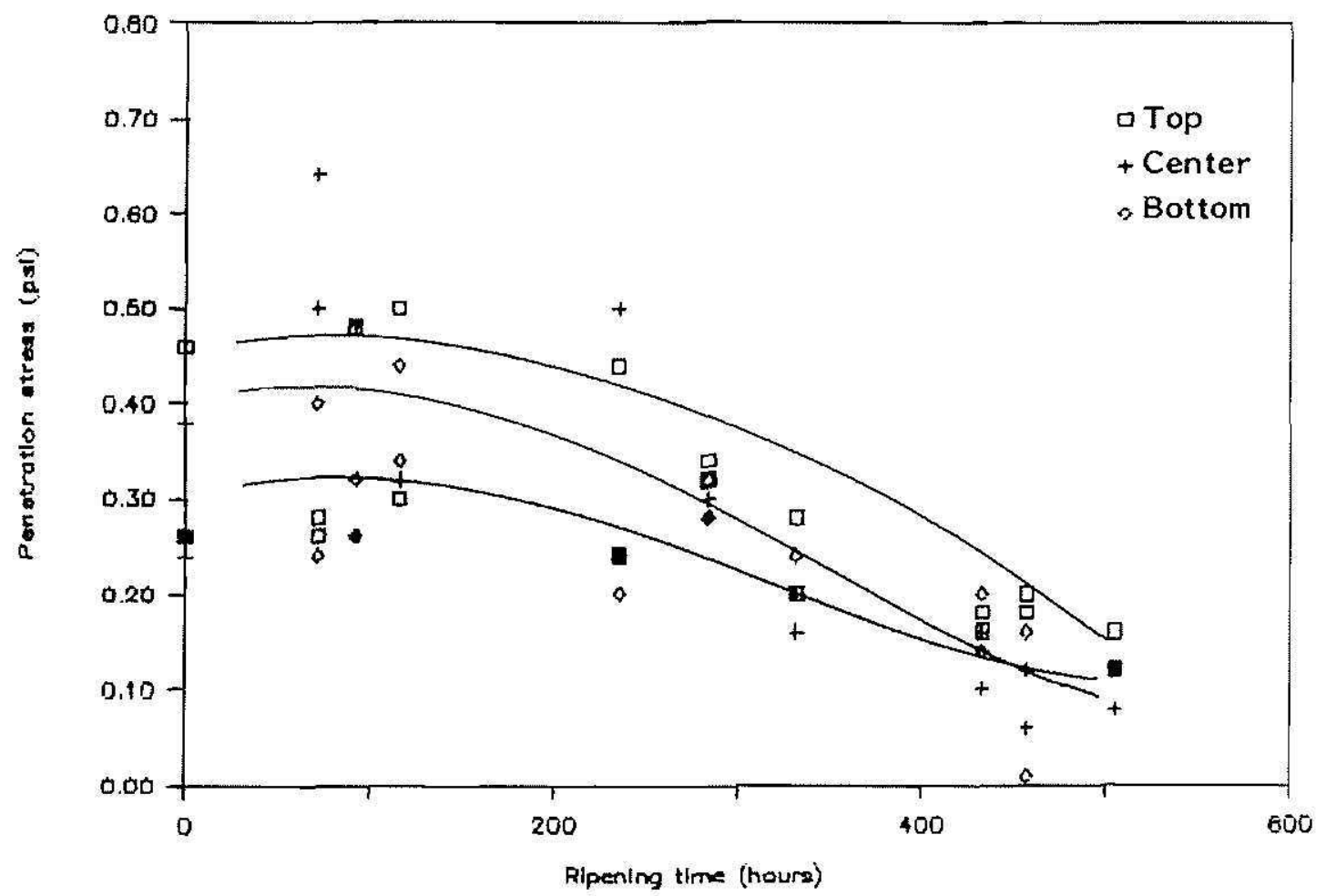

FIG. 10.-Ripening profiles of pineapple fruit at $0.366 \mathrm{~cm} / \mathrm{s}$ penetration velocity. 


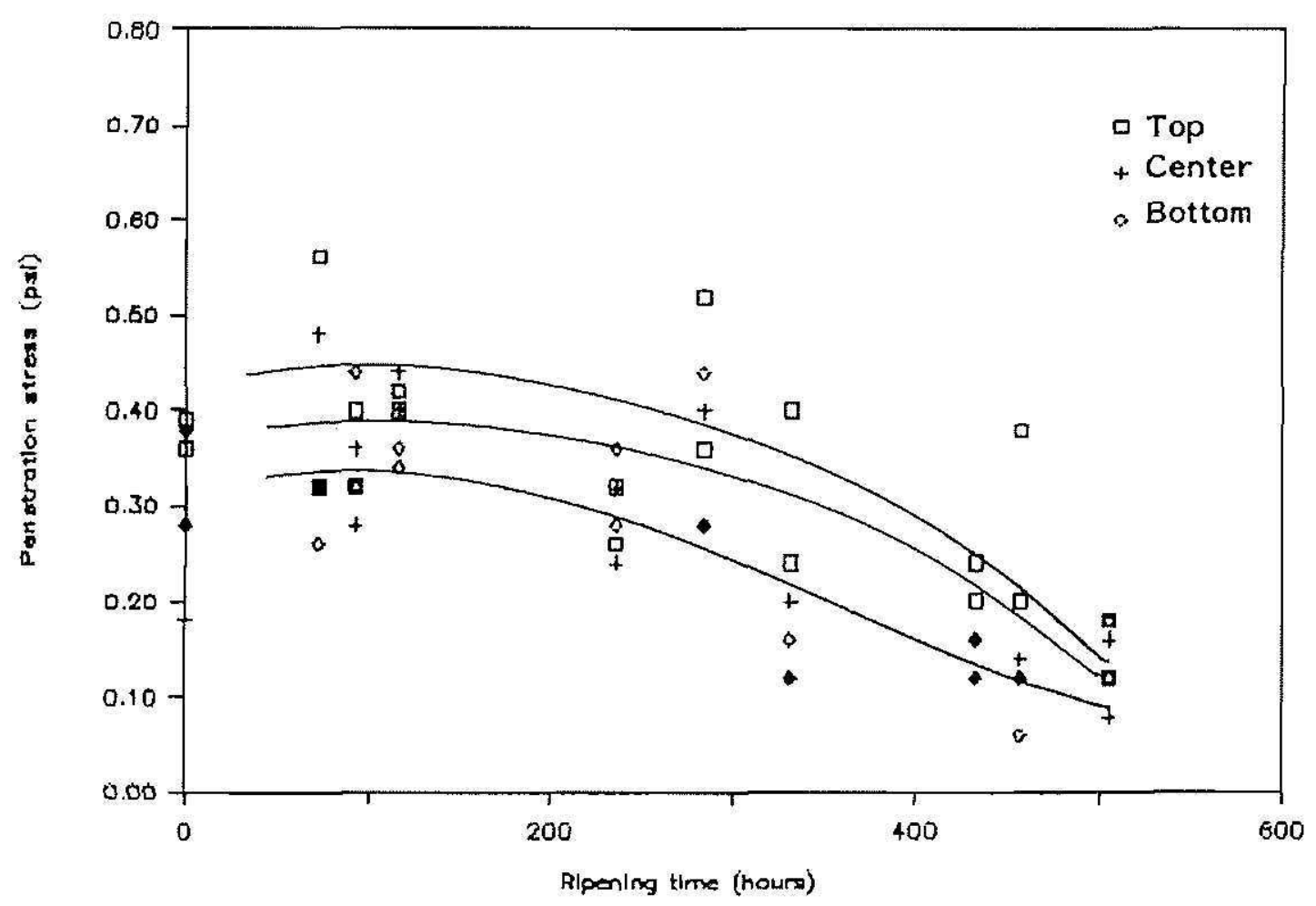

FIG. 11.-Ripening profiles of pineapple fruit at $0.600 \mathrm{~cm} / \mathrm{s}$ penetration velocity.

Results reported herein demonstrate the feasibility of using the penetration stress measurement as an index for ripening level classification of pineapples. The establishment of standard maximum penetration stress curves as a function of ripening time may be obtained for other fruits such as mangoes, papayas and guavas.

\section{LITERATURE CITED}

1. A.O.A.C., 1984. Official methods of analysis of the Association of Official Analytical Chemists. 14th. Association of Official Analytical Chemists, Inc. Arlington, Virginia.

2. Bourne, M., 1973. Use of the penetrometer for deformation testing of foods. J. Food Sci. 38, 720-21.

3. J., C. Moyer and D. B. Hand, 1966. Measurement of food texture by a Universal Testing Machine. Food Technol. 20, 522-26.

4. $\longrightarrow$ 1968. The extrusion principle in texture measurement of fresh peas. Food Technol. 22, 1013-18.

5. Cancel, H. L. and T. García, 1979. Fruit set as an index for harvesting Edward mangoes. J. Agric. Univ. P. R. 63 (1): 31-4.

6. Fletcher, S., 1971. Mechanical behavior of processed apples. Trans. ASAE. 11 (1): 14-6.

7. Wang, J. and H. Chang, 1970. Mechanical properties of papaya and their dependence on maturity. Trans. ASAE. 13, 369-71.

8. Wills, R. H., T. H. Lee, D. Graham, W. B. McGlasson and E. G. Hall, 1981. Postharvest. An introduction to the physiology and handling of fruit and vegetables. The AVI Publishing Company Inc., Westport, Conn. 